\title{
Lactose malabsorption in Polynesian and white children in the south west Pacific studied by breath hydrogen technique
}

\author{
J M SEAKINS, R B ELLIOTT, C M QUESTED, A MATATUMUA
}

\begin{abstract}
Lactose malabsorption was studied by a breath hydrogen technique in 139 Samoan and 68 white schoolchildren. The Samoans were studied in four locations, two in Western Samoa and two in New Zealand, and the white children in both the Cook Islands and New Zealand. The prevalence of malabsorption varied with location: for Samoans it ranged from $41 \%$ to $60 \%$ in Western Samoa and $0 \%$ to $35 \%$ in New Zealand; white children had rates of $27 \%$ in the Cook Islands and $5 \%$ in New Zealand. Environmental factors rather than genetic factors are likely to play the main part in initiating if not perpetuating lactose malabsorption.

In both races lactose malabsorption had no effect on the acceptance of, consumption of, and number of gastrointestinal symptoms caused by milk and milk biscuits. Children who had symptoms after consuming a particular dairy product were more likely to say they disliked it than those who reported no symptoms.
\end{abstract}

\section{Introduction}

Acquired lactose malabsorption occurs in many populations of healthy children and adults throughout the world. The prevalence increases with age and is greater in dark skinned races and in tropical areas. ${ }^{1-4}$ The condition may be part of normal development, due to a genetically determined decline in lactase activity, or secondary to damage of the intestinal mucosa by gastrointestinal disease, parasites, or malnutrition. ${ }^{5-8}$ Subjects with lactose malabsorption can experience lactose intolerance and suffer from gastrointestinal symptoms such as abdominal bloating and pain, flatulence, and diarrhoea. ${ }^{9}$

To date little has been reported on lactose malabsorption in Polynesians, who are a dark skinned race of people from the Pacific region..$^{10}$ This study compared the prevalence of lactose malabsorption in Samoan and white children living on tropical islands in the south west Pacific and in New Zealand. Samoan children were selected as they are of relatively pure Polynesian extraction. Possible causes for the lactose malabsorption were examined. We also investigated the effect of lactose malabsorption on the consumption and acceptability of milk and milk biscuits and whether the quantitites of these products normally consumed caused gastrointestinal symptoms.

\section{Subjects and methods}

One hundred and thirty nine Samoan and 68 white children, aged 6 to 13 years, were studied at schools in five locations. The study locations were

\footnotetext{
Department of Paediatrics, School of Medicine, University of Auckland, Auckland, New Zealand

J M SEAKINS, PHD, FNZIC, scientist

R B ELLIOTT, MD, FRACP, professor of child health research

C M QUESTED, BSC, research technician

A MATATUMUA, MB, CHB, medical practitioner

Correspondence to: Professor Elliott.
}

chosen to enable comparison of tropical and temperate environments and differing socioeconomic backgrounds. In New Zealand two groups of children were chosen from Auckland city: one from a low income suburb and the other from a moderately wealthy area as determined from data on income. ${ }^{11}$ In Western Samoa one group of children was drawn from a poor village school and the other from the elite school in the island group. In the Cook Islands subjects were chosen from the best school in the island group and were largely children of highly paid contract workers. Study groups of similar mean age were selected at each location.

Lactose malabsorption was diagnosed by measuring breath hydrogen excretion under non-fasting physiological conditions. The children consumed $10 \mathrm{~g}$ of lactose in $100 \mathrm{ml}$ of an orange flavoured, carbohydrate free cordial, and a breath sample was collected three hours later. The breath samples were collected by a single rebreathing technique that entailed blowing into an aluminium foil laminate bag, inhaling the contents, and reinflating the bag. The technique was found to give good correlation ( $R=$ 0.98 ) with the well established Haldane-Priestley. method. ${ }^{12}$ The bags were made from aluminium-plastic laminate $(900 \mathrm{ml})$ with a rubber mouth tube; they were sterilised with ethylene oxide and aerated before use. Storage studies showed no loss of hydrogen over 1000 hours.

As soon as possible after collection (in no case more than five hours) the breath samples were pretreated with Carbosorb to remove carbon dioxide and with silica gel to remove water vapour before hydrogen analysis by gas chromatography. Analysis was performed by detection of thermal conductivity after separation on a molecular sieve type $5 \mathrm{~A}$ column. Standard gas mixtures were used to check the calibration of the instruments at each location. A breath hydrogen content of $18 \mathrm{ppm}$ or more at three hours after lactose was consumed was taken as indicative of lactose malabsorption. The validity of this technology is described elsewhere. ${ }^{4}$

An illustrated questionnaire was prepared to determine attitude to, usua intake of, and frequency of symptoms after consumption of milk and milk biscuits. These products were chosen as they were important sources of lactose in the diet-milk in all the survey groups and milk biscuits in the Pacific Islands. Attitude was graded on a hedonic scale, and intake was determined by both the usual amount consumed and the frequency of consumption. Lactose intolerance was assessed by the association of gastrointestinal symptoms with consumption of each of the dairy products and by asking the children whether they experienced any gastrointestinal symptoms during the 24 hours after the $10 \mathrm{~g}$ lactose challenge. Each child was helped in filling out the questionnaire, which was translated into Samoan for use in Western Samoa. The accuracy of the questionnaire was checked to eliminate anomalous responses such as "I hate milk" but "I want more milk than I am getting."

Differences in the prevalence of lactose malabsorption at different study locations and the relation between acceptance of dairy products and symptoms were analysed by $\chi^{2}$ test or Fisher's exact test. A KolmogorovSmirnov two sample test was used to compare the intake of dairy products of those who experienced gastrointestinal symptoms with that of those who did not. An analysis of variance was used to test for differences in age between lactose absorbers and malabsorbers.

\section{Results}

Table I shows the prevalence data for lactose malabsorption. For each race there was a significant difference in the prevalence of lactose malabsorption between the different study locations (Samoans $\chi^{2}=19 \cdot 6, v=3, p<0.001$ white children $\mathrm{p}<0.02$ ). For Samoan children in both New Zealand and Western Samoa the prevalence was higher in the poorer socioeconomic areas. The difference was not significant $(p=0.09)$ for Western Samoa but was significant $(p=0.01)$ for New Zealand. Direct comparison between Samoan and white children was possible only in the New Zealand low socioeconomic area. White children had a significantly lower prevalence of lactose malabsorption $(p<0.005)$. There was no apparent relation between the prevalence of lactose malabsorption and lactose intake from milk.

At each location malabsorption had no effect on the intake and acceptance of milk and milk biscuits or the number of gastrointestinal symptoms the 
TABLE I-Prevalence of lactose malabsorption and usual intake of lactose from milk in the two groups of children

\begin{tabular}{|c|c|c|c|c|c|}
\hline Location & $\begin{array}{l}\text { Socioeconomic } \\
\text { rating }\end{array}$ & $\begin{array}{c}\text { No } \\
\text { studied }\end{array}$ & $\begin{array}{c}\text { No }(\%) \text { with } \\
\text { lactose } \\
\text { malabsorption }\end{array}$ & $\begin{array}{c}\text { Age range } \\
\text { (years) }\end{array}$ & $\begin{array}{c}\text { Daily mean (SD) } \\
\text { lactose intake } \\
\text { from milk } \\
\text { (g/day) }\end{array}$ \\
\hline Western Samoa & $\left\{\begin{array}{l}\text { Low } \\
\text { High }\end{array}\right.$ & $\begin{array}{l}\text { Samoa } \\
80 \\
22\end{array}$ & $\begin{array}{l}\text { In children } \\
48(60) \\
9(41)\end{array}$ & $\begin{array}{r}6-10 \\
10-13\end{array}$ & $\begin{array}{r}8(16) \\
10(11)\end{array}$ \\
\hline New Zealand & $\begin{array}{l}\text { Low } \\
\text { Moderate }\end{array}$ & $\begin{array}{l}23 \\
14\end{array}$ & $\begin{array}{l}8(35) \\
0\end{array}$ & $\begin{array}{l}8-11 \\
6-15\end{array}$ & $\begin{array}{l}31(32) \\
12(14)\end{array}$ \\
\hline \multicolumn{6}{|c|}{ White children } \\
\hline New Zealand & Low & 42 & $2(5)$ & $7-11$ & $36(37)$ \\
\hline
\end{tabular}

*Socioeconomic rating not comparable from country to country but relative to country of study.

children experienced after consuming their usual intake of milk and milk biscuits (table II). There was no difference in the mean age of absorbers and malabsorbers at each location. None of the children reported gastrointestinal symptoms during the 24 hours after the $10 \mathrm{~g}$ lactose challenge.

Analysis of anomalous responses indicated that children had tried to prevalence for Samoans in both New Zealand and Western Samoa. Living on a tropical Pacific island also seems to confer an increased risk of lactose malabsorption in children, irrespective of race. In the white children this occurred despite those in the tropics being more affluent. A greater frequency of gastrointestinal infections, parasites, and malnutrition in the tropics and the poor environment may account for the higher rates of malabsorption. Certainly Samoan children in Western Samoa show evidence of nutritional inadequacy that does not occur in New Zealand ${ }^{13}$ and they are commonly infected with parasites. ${ }^{14}$

There are few reports indicating that environmental factors may increase the prevalence of lactose malabsorption. Lindenbaum et al reported that Europeans living in Pakistan had a similar prevalence of malabsorption and jejunal abnormalities to that in the native Pakistani laboratory workers. ${ }^{15}$ Habte et al reported that Scandinavian children living in Ethiopia had a higher prevalence of lactose malabsorption (25\%) than children in Scandinavia (1-5\%). ${ }^{16}$ Brown et al showed that breast fed Bangladeshi children had a significantly $(p<0.007)$ lower prevalence of lactose malabsorption $(42.3 \%)$ than weaned children of a similar age $(90 \cdot 9 \%) .{ }^{17}$ They concluded that some proportion of lactose malabsorption between the ages of 19

TABLE II-Intake of milk and milk biscuits, acceptance, and symptoms related to lactose absorbing state

\begin{tabular}{|c|c|c|c|c|c|c|c|c|c|}
\hline \multirow[b]{2}{*}{ Location } & \multirow[b]{2}{*}{ Socioeconomic rating ${ }^{\star}$} & \multirow{2}{*}{$\begin{array}{l}\text { Lactose } \\
\text { absorbing } \\
\text { state }\end{array}$} & \multirow[b]{2}{*}{ No studied } & \multicolumn{2}{|c|}{ Daily lactose intake from: } & \multicolumn{2}{|c|}{$\begin{array}{l}\text { No (\%) of } \\
\text { children who liked: }\end{array}$} & \multicolumn{2}{|c|}{$\begin{array}{l}\text { No (\%) of } \\
\text { children with symptoms from: }\end{array}$} \\
\hline & & & & $\begin{array}{c}\text { Milk } \\
\text { (g/day (SD)) }\end{array}$ & $\begin{array}{l}\text { Milk biscuits } \boldsymbol{T} \\
\text { (g/day (SD)) }\end{array}$ & Milk & Milk biscuitst & Milk & Milk biscuits $†$ \\
\hline \multirow{2}{*}{ Western Samoa } & Low & $\left\{\begin{array}{l}\text { Absorber } \\
\text { Malabsorber }\end{array}\right.$ & $\begin{array}{l}\text { Samoa } \\
32 \\
48\end{array}$ & $\begin{array}{c}\text { children } \\
5(9) \\
9(19)\end{array}$ & $\begin{array}{l}6(10) \| \\
5(9) \|\end{array}$ & $\begin{array}{ll}28(88) \\
40(83)\end{array}$ & $\begin{array}{ll}28 & (88) \\
43 & (90)\end{array}$ & $\begin{array}{l}4(13) \\
9(19)\end{array}$ & $\begin{array}{l}4(13) \| \\
5(11) \|\end{array}$ \\
\hline & High & $\left\{\begin{array}{l}\text { Absorber } \\
\text { Malabsorber }\end{array}\right.$ & $\begin{array}{r}13 \\
9\end{array}$ & $\begin{array}{r}13(10) \\
6(10)\end{array}$ & $\begin{array}{l}10(16) \\
12(15)\end{array}$ & $\begin{array}{l}13(100) \\
9(100)\end{array}$ & $\begin{array}{r}13(100) \\
9(100)\end{array}$ & $\begin{array}{l}1(8) \\
1(11)\end{array}$ & $\begin{array}{l}1(8) \\
1(11)\end{array}$ \\
\hline \multirow{2}{*}{ New Zealand } & Low & $\left\{\begin{array}{l}\text { Absorber } \\
\text { Malabsorber }\end{array}\right.$ & $\begin{array}{r}15 \\
8\end{array}$ & $\begin{array}{l}33(37) \\
27(23) \|\end{array}$ & & $\begin{array}{r}14(93) \\
6(75)\end{array}$ & & $\underset{\ddagger}{\ddagger}$ & \\
\hline & Moderate & $\left\{\begin{array}{l}\text { Absorber } \\
\text { Malabsorber }\end{array}\right.$ & $\begin{array}{r}14 \\
0\end{array}$ & $12(14) \|$ & & $13(93)$ & & $1(7)$ & \\
\hline \multicolumn{10}{|c|}{ White children } \\
\hline Cook Islands & High & $\left\{\begin{array}{l}\text { Absorber } \\
\text { Malabsorber }\end{array}\right.$ & $\begin{array}{r}19 \\
7\end{array}$ & $\begin{array}{l}21(40) \\
20(24)\end{array}$ & $\begin{array}{l}2(5) \| \\
6(15)\end{array}$ & $\begin{aligned} 17 & (89) \\
6 & (86)\end{aligned}$ & $\begin{array}{c}12(63) \\
5(83)\end{array}$ & $\begin{array}{l}2(11) \\
0\end{array}$ & $\begin{array}{l}1(6) \| \\
0\end{array}$ \\
\hline New Zealand & Low & $\left\{\begin{array}{l}\text { Absorber } \\
\text { Malabsorber }\end{array}\right.$ & $\begin{array}{r}40 \\
2\end{array}$ & $\begin{array}{l}36(37) \uparrow \\
24 \S \|\end{array}$ & & $\begin{array}{l}35(92) \uparrow \\
2(100)\end{array}$ & & $\begin{array}{l}5(21)^{\star \star} \\
1(100) \oint \|\end{array}$ & \\
\hline
\end{tabular}

* Socioeconomic rating not comparable from country to country but relative to country of study. †Milk biscuits not available in New Zealand.

$\ddagger$ Question not asked at this location.

§Small number in group.

|No data for one child.

INo data for two children.

$\star$ No data for 16 children.

answer the questionnaire correctly. None of the children reported hating milk but wanting more.

Children who reported gastrointestinal symptoms after drinking milk were less likely to say that they liked milk $(p<0.001)$ than those who reported no symptoms: the 24 ( $14 \%$ of the 167 who answered the question) with symptoms had a mean intake of lactose from milk of 10 (SD 14) g/day and 13 (54\% of those with symptoms) liked milk; the 143 children who had no symptoms had a mean intake of 13 (22) g/day, and 135 (94\%) liked milk. The same was true for children who reported symptoms from milk biscuits: they were more likely to dislike them $(p<0 \cdot 001)$. Of the $12(10 \%$ of 123 children who were asked this question) with symptoms who had a mean intake of lactose from milk biscuits of 7 (13) g/day, six liked them; of the 111 $(90 \%)$ without symptoms who had a mean intake of $6(11) \mathrm{g} /$ day, $104(94 \%)$ liked them.

In both cases equal numbers of absorbers and malabsorbers reported symptoms. In the Pacific Islands, where children were asked about both milk and milk biscuits, one half of those who perceived symptoms after drinking milk did not report symptoms after eating milk biscuits, and a third of those with symptoms after eating milk biscuits did not report symptoms after drinking milk. Malabsorbing state made no difference to whether children reported symptoms to one or both dairy products.

\section{Discussion}

Clearly environmental factors are important in the development of lactose malabsorption. Less affluent surroundings increase the months and 5 years was secondary rather than genetically controlled because $39 \%$ of the children absorbed lactose normally on repeat testing three to five months later.

The possibility that genetic influences may account for some of the lactose malabsorption cannot be discounted. When compared in the same locations (New Zealand low socioeconomic) Samoan children had a significantly greater prevalence of lactose malabsorption than white children; environmental factors, however, may also explain this difference. If the socioeconomic rating had been assigned on an individual basis, rather than to the study area as a whole, differences in the home environments of the races might have been evident, which would have explained the different prevalences. Further study is necessary to resolve this question.

Our data do not support the hypothesis that lactose malabsorption is an adaptation to low lactose intakes. Traditionally, dairy products were not consumed in the Pacific Islands; the introduction of Western food habits, however, has made them widely available.

The use of milk and milk biscuits in supplementary feeding programmes in Western Samoa has been questioned. Controversy focuses on the fact that people with malabsorption may suffer adverse symptoms after consuming food containing lactose. In the present study, as in others on children of the same age ${ }^{318}$ there was no evidence of reduced consumption or changed attitude to milk or milk biscuits due to lactose malabsorption. In addition, no children reported any gastrointestinal symptoms after the $10 \mathrm{~g}$ test dose of 
lactose. In view of these results we find no reason to discourage the provision of milk and milk biscuits for supplementary feeding programmes on the basis of high rates of lactose malabsorption among Western Samoan children.

In this study children were asked to report the occurrence of gastrointestinal symptoms after their usual intake of milk and milk biscuits as an indicator of lactose intolerance. In fact, both children with and without malabsorption complained of symptoms, a finding already reported by Stephenson and Latham. ${ }^{19}$ This lack of association between symptoms and lactose malabsorption is not surprising as abdominal pains, gas, and diarrhoea are non-specific and may be caused by several factors apart from lactose malabsorption. Possible explanations may be intolerance to other milk components $^{8}$ or dislike of the taste of milk or milk biscuits. Although gastrointestinal symptoms proved to be an unreliable predictor of lactose intolerance, they did indicate intolerance to milk or milk biscuits as they were significantly related to acceptance of these products.

This study suggests that a genetic predisposition cannot be the sole cause for lactose malabsorption among Samoan and white children. Geographical and socioeconomic factors probably play an important part in the onset of the condition and its perpetuation. Lactose malabsorption did not seem to be a factor in the rejection of milk and milk biscuits by children. Gastrointestinal symptoms after the usual intake of milk and milk biscuits were not related to lactose malabsorption.

We acknowledge the help of the staff of the departments of health in Western Samoa and the Cook Islands; Flatbush Primary School, Auckland, New Zealand; Falefitu and Apia Primary Schools, Western Samoa; and Avatea Primary, the Cook Islands. The research was supported by the Harold Thomas Rotary Trust (New Zealand); Roussel (New Zealand) Ltd; National Children's Health Research Foundation (New Zealand); and the Ministry of Agriculture and Fisheries, New Zealand.

\section{References}

1 Suhariono S, Burdiarso A, Sutedjo R. Lactose malabsorption in 'healthy' Indonesian pre-school children. Paediatr Indones 1971;11:251-4.

2 Bolin TD, Davis AE, Seah CS, et al. Lactose intolerance in Singapore. Gastroenterology 1970;59. 76-84.

3 Woteki CE, Elliott W, Young EA. Lactose malabsorption in Mexican-American children. Am $\mathcal{f}$ Clin Nutr 1976;29:19-24.

4 Nose O, lida Y, Kai H, Harada T, Ogawa M, Yabuuchi H. Breath hydrogen test for detecting lactose malabsorption in infants and children. Prevalence of lactose malabsorption in Japanese children and adults. Arch Dis Child 1979;54:436-40.

5 Lisker R, Gonzalez B, Daltabuit $M$. Recessive inheritance of the adult type of intestinal lactase deficiency. Am J Hum Genet 1975;27:662-4.

6 Carrera E, Nesheim MC, Crompton DWT. Lactose maldigestion in ascaris-infected preschool children. Am f Clin Nutr 1984;39:255-64.

7 Hyams JS, Krause PJ, Gleason PA. Lactose malabsorption following rotovirus infection in young children. I Pediatr 1981;99:916-8.

8 Walker-Smith JA. Milk intolerance in children. Clin Allergy 1986;16:183-90.

9 Lifshitz F. Acquired carbohydrate intolerance in children. Clinical manifestations and therapeutic recommendations. In: Paige DM, Bayless TM, eds. Lactose digestion, clinical and nutritional implications. Baltimore, Maryland: Johns Hopkins University Press, 1981:182-93.

10 Abbott WGM, Tasman-Jones C. Incidence of acquired primary hypolactasia in three New Zealand racial groups. NZ Med f 1985;98:228-9.

11 New Zealand census of population and dwellings, 1981. Bulletin 2-central Auckland region. Wellington, New Zealand: Department of Statistics, 1982. (Department of Statistics catalogue No 02.302.)

12 Metz G, Gassull MA, Leeds AR, Blendis LM, Jenkins DJA. A simple method of measuring breath hydrogen in carbohydrate malabsorption by end expiratory sampling. Clinical Science and Molecular Medicine 1976;50:237-40.

13 Lines DR, Anderson NE, Gorman DF. The nutritional status of children in Western Samoa. $f$ Trop Pediatr 1980;26:88-95.

14 Wood CS, Gans LP. Some hematological findings in children of Western Samoa. 7 Trop Pediatr 1984;30:104-10.

15 Lindenbaum J, Harmon JW, Gerson CD. Subclinical malabsorption in developing countries. Am f Clin Nutr 1972;25:1056-61.

16 Habte D, Sterky G, Hjalmarsson B. Lactose malabsorption in Ethiopian children. Acta Paediatr Scand 1973;62:649-54.

17 Brown KH, Parry L, Khatun M, Ahmed MG. Lactose malabsorption in Bangladeshi village children: relation with age, history of recent diarrhea, nutritional status and breast feeding. $\mathrm{Am}$ f Clin Nutr 1979;32:1962-9.

18 Garza C, Scrimshaw NS. Relationship of lactose intolerance to milk intolerance in young children. Am f Clin Nutr 1976;29:192-6.

19 Stephenson LS, Latham MC. Lactose intolerance and milk consumption: the relation of tolerance to symptoms. Am J Clin Nutr 1974;27:296-303.

(Accepted 21 fuly 1987)

\section{ONE HUNDRED YEARS AGO}

Perhaps it is hardly to be expected that our daily contemporaries should all of them seek to ascertain whether a statement is true before they publish it, for were they to do so, many of their most sensational catchpenny articles would never be printed. The case is particularly hard when a statement about "alleged inhuman conduct," as one of the evening papers put it, concerns a large charitable institution, and especially when like Guy's Hospital, it is appealing for funds. The accounts of the patient Stack in the papers recently were most misleading. The facts are, that he went to Guy's with a broken fibula on March 14th, at 7 pm was immediately washed and put to bed, and had sandbags placed on either side of the injured limb, which was put up in a plaster-of-Paris splint at $11 \mathrm{pm}$; the patient was discharged the next day with a pair of crutches, after it had been seen that the splint was in good order. The points to be noted are that it is the usual custom that a simple fracture of the fibula should be taken in for a plaster-of-Paris splint to be put on, and that the patient should be discharged with crutches next day, when the plaster has set. There is in reality no room in Guy's, or in most of the other hospitals, for mere accidents, and therefore cases of slight fracture, such as those of the fibula, cannot be kept as in-patients. On the south of the Thames the pressure is exceptionally felt, there being no hospital nearer in a westerly direction than St Thomas's, and none whatever to the east of Guy's. On the night during which Stack was in the hospital, the accident ward was so crowded that one of the patients had to sleep upon a stretcher, and the dresser in charge put up five fractures in the wards between dinner and bedtime. The man's statement that he was charged two shillings for a pair of crutches is absolutely untrue. Usually the hospital authorities make those patients who require to take crutches out with them deposit two shillings, which is returned when the crutches are given back; this rule was waived in this patient's case. Dr Steele's letter, which appeared in the daily papers the next day showed, as do the above facts, that there was in reality no foundation for the allegation of inhuman conduct. Unfortunately, the allegation is much more likely to remain in people's minds than the denial of it, and people who do see the denial are generally but too ready to shrug their shoulders and say "there must be something in it after all." It would be a real kindness to hospitals, equivalent to many subscriptions, if the newspapers would be charitable enough to refrain from publishing allegations until the reporter who supplies the "copy" has paid a visit to the hospital, and "interviewed" the house-surgeon or other official on duty. (British Medical fournal 1887;i:741.)

The first session of the General Medical Council, as enlarged by the Medical Act of 1886, will commence on February 15 th. There is a great deal of work to be got through, and we understand that some of the newly-elected members will lose no time before taking a prominent part in the business of the Council, for they have already given notice of a motion with regard to the desirability of reviving the apprenticeship system. The Council will be called upon at once to make arrangements for carrying out certain of the provisions of the Act of 1886; it will, for instance, be necessary to draw up the regulations under which the Inspectors of Examinations are to act, and to assign salaries; for these posts it is likely there will be no lack of candidates, and the selection of the most suitable persons will probably be no easy task. The conditions under which colonial and foreign degrees and diplomas shall be admitted will be another matter which must be settled. The appointments of Examiners in Surgery to act at the Society of Apothecaries of London, and at the Apothecaries' Hall of Ireland, which will be rendered necessary if the Colleges persist in their refusal to admit these two bodies to the Conjoint Board in England and Ireland respectively, will doubtless lead to a prolonged debate, in which the direct representatives of the profession will be able to take part with emphasis and authority. The duty of the Council with regard to unqualified assistants who practise in "branch dispensaries" under circumstances which render them practically independent of the qualified practitioners who yet act as the legal "cover," will probably also be discussed. Altogether, it will be seen that there is every likelihood that the coming session will not only have important business to transact, but will have before it controversial topics, which are almost sure to be debated at great length. (British Medical fournal 1887;i:293.) 